Original Article

\title{
Highland amphibians - Recalculation of data from 1990 to 2010 on the effects of extremely diluted thyroxine
}

\author{
Gerhard Lingg and Peter Christian Endler \\ Interuniversity College for Health and Development Graz / Castle of Seggau
}

\begin{abstract}
Experiments on amphibian metamorphosis can vary considerably in duration. The authors had set themselves the task of defining a generally applicable pooling method for metamorphosis experiments. The problem of artificial differences in variability when comparing and pooling data from several experiments was approached by normalization with respect to time based on the development of both test and the control animals. The range from $0 \%$ to $100 \%$ over which the fraction of four-legged animals progresses in the course of an experiment is divided into $10 \%$ intervals and the $10 \%$ reference points are mapped on a corresponding scale. Each measurement is then assigned to the point on the time scale to which it is closest. In this way each reference point is assigned a value giving the number or percentage of four-legged animals at that point on the scale. Subsequent analysis was then based on the individual values for the test and control groups that corresponded to the joint $10 \%$ reference point. Normalization respect to time was done on the assumption that differences in metamorphosis speed attributable to treatment would override differences in duration between experiments. The results of experiments performed over the course of two decades (1990 - 2010) on highland Rana temporaria treated with a homeopathically prepared high dilution of thyroxine (“30x") are presented in full detail based on this normalization method. Differences found between treatment groups thus calculated were in line with those obtained with other pooling methods. Thyroxine 30x does slow down metamorphosis in inert highland amphibians. This was observed by five researchers in 20 subexperiments, and it seems to be the most reliable bio-assay found in amphibian research on homeopathy so far. When experiments were performed with highland animals pretreated by hyperstimulation with molecular thyroxine, slowing down of metamorphosis was again observed (by three out of four researchers) in most of 10 sub-experiments.
\end{abstract}

Keywords: homeopathy, thyroxine, amphibians

\section{Introduction}

Sensitivity of amphibian metamorphosis to homeopathically prepared highly diluted substances, i.e. metal salts, was first reported by König in the 1930s [1]. In 1989/1990, the work group of Endler adapted the model by using high dilutions of the metamorphosis hormone thyroxine [2]. In various studies on this non-invasive experimental model, Rana temporaria larvae at different stages from different biotopes were treated with different homeopathically prepared dilutions ("potencies") of thyroxine applied at different time intervals. Analogously prepared solvent (water) was used as control. Animals were either inert or hyperstimulated by treatment with molecular thyroxine. Development was monitored by documenting the number of animals that entered the four-legged stage at given time-points [3-6] or the animals' climbing activity [7]. As a rule experiments were performed by different researchers in parallel. All experiments were performed blind.

Inert lowland amphibians were found not to visibly react to potencies of thyroxine, but a low dilution of this hormone can slow down metamorphosis in lowland amphibians, when these had first been hyperstimulated 
with thyroxine in molecular dose [5]. In other words, pretreatment with molecular thyroxine can enhance a reverse or 'curative' effect of a low potency of thyroxine. However, amphibians from lowland biotopes were found not to visibly react to high potency thyroxine $30 \mathrm{x}$.

In contrast, thyroxine 30x does slow down metamorphosis in highland amphibians. This was observed by five researchers in most of 20 sub-experiments in inert animals, and it seems to be the most reliable bio-assay found in our amphibian research so far [3-5]. When the experiment was performed with animals pretreated by hyperstimulation with molecular thyroxine, slow down of metamorphosis was again observed (by three out of four researchers) in most of 10 sub-experiments.

These results are complemented by data from independent amphibian studies performed in Brazil [8,9], and a pilot study performed in 2010 by a colleague from the Kollegiale Instanz für Komplementärmedizin of Bern University [10].

When comparing and evaluating the data, we had to take into account that experiments in highland amphibian varied in duration (most ranging 8-14 days, but some taking up to 26 days). This problem in comparing and pooling data from several experiments was approached in several manners in earlier publications, for example by considering quartiles of the total duration, as proposed by Roeland van Wijk [3] or by normalizing data with respect to time based on the development of animals in water 30x-control group, as recommended by Rainer Lüdtke [11, p 162].

In general, all the different methods of presenting and pooling data led to results pointing to a same tendency. However, we had set ourselves the task of defining a generally applicable pooling method for metamorphosis experiments on amphibian larvae. Together with statistician Harald Lothaller (formerly Graz University) we reviewed the various methods used in the past and finally arrived at the procedure presented here.

The aim of this paper is to present full details of the results obtained on highland Rana temporaria treated with thyroxine 30x in the course of two decades (1990 - 2010) using a defined normalization method for comparability.

\section{Methods}

On highland Rana temporaria, the following sub-studies were performed:

(1) inert highland animals and thyroxine 30x

(2) thyroxine hyperstimulated highland animals and thyroxine 30x

These experiments were inspired by the appeal of intoxication studies as an interesting tool for research in the field of homeopathy: an organism is first intoxicated with a molecular agent and then an attempt at detoxification or 'cure' is made by applying the same agent in diluted / agitated ('potentiated') form. Our initial choice of the amphibian model was motivated by the fact that during metamorphosis, a rapid increase of the thyroxine level occurs in the animals that may justify the notion of an 'exceptional' (albeit not intoxicated) state in studies type (1). In studies type (2), animals are artificially hyperstimulated with molecular thyroxine (i.e. 'intoxicated') before thyroxine in potentiate form is applied.

\section{(1) Inert highland animals and thyroxine 30x}


Study type (1) concerns the influence of thyroxine 30x compared to water 30x on inert highland animals. Rana temporaria larvae were taken from highland biotopes $(1,400-1,600 \mathrm{~m}$ above sea-level, which in southern Styria is just above the tree-line) [3-5].

A stock solution was prepared from tetraiodothyronine sodium pentahydrate ( $\mathrm{T}_{4}$, Sigma) diluted $10^{-4}$ parts by weight in $40 \%$ vol. ethanol in the experiments performed in the 1990, and in pure water in the experiments performed in or after $2000(2000 \mathrm{~s})$. To prepare of test solution thyroxine 30x, the stock solution $\left(10^{-4}\right)$ was further diluted with pure double distilled water in 26 1:10 steps at ambient temperature and agitated after each dilution step according to a standardized protocol: using disposable pipettes, $1 \mathrm{ml}$ of the precedent dilution was added to $9 \mathrm{ml}$ of water in a $20 \mathrm{ml}$ vial. Then the vial was banged 30 times against a rubber impediment at approximately $0.5 \mathrm{sec}$ intervals to create mechanical shocks. For preparation of control, $40 \%$ ethanol (1990s) or pure water (2000s ) was analogously further diluted with pure double distilled water in 26 1:10 steps and agitated after each dilution step (water 30x). Final (theoretical) thyroxine concentration of thyroxine $30 \mathrm{x}$ in the basin water was $10^{-35}$ parts by weight after the first application. Three $\mu 1$ of probe dilutions (thyroxine 30x or water 30x) were added per animal and $300 \mathrm{ml}$ of basin water at 48-hour intervals.

The starting stage was defined as the point when the hind legs of two-legged tadpoles are straddled so that one can merely see through the triangle formed by thigh, shank, and tail (figure 1, left). This point of development occurs during Gosner's stage 31 [12]. Tadpoles were observed until the forelegs, which are preformed under the skin, broke through and animals had thus entered the four-legged stage (figure 1, right).
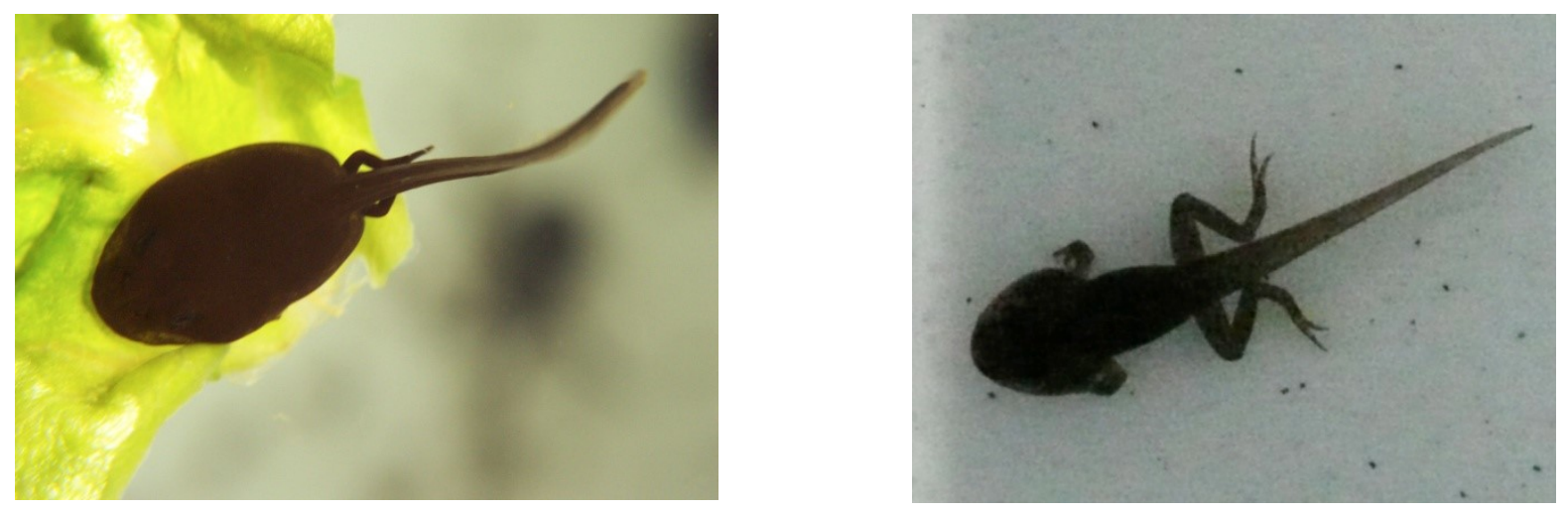

Figure 1: left: Rana temporaria larvae at the defined teo-legged-stage when experiments started. right: Defined four-legged stage when development is monitored.

The number of animals per basin varied from nine to 20 in different experiments; however the amount of basin water per animal was constantly $300 \mathrm{ml}$. An equal number of animals (see table 1 in the Results section) were allotted to white plastic basins according to a random procedure, ensuring that animals were distributed homogenously in terms of their level of activity and swimming behavior in the main tub. The experimental design was the same at each center. Basins were arranged in rows (figure 2), each row containing an equal number of basins for each treatment group. The spatial arrangement of groups within rows rotated from one row to the next, i.e. basins with identical treatment groups were arranged in diagonals, and was left unchanged throughout the experiment to avoid the danger of cross-contamination by means of splashing. Indirect natural light was used. Tadpoles were fed blanched greens (lettuce) ad libitum. 


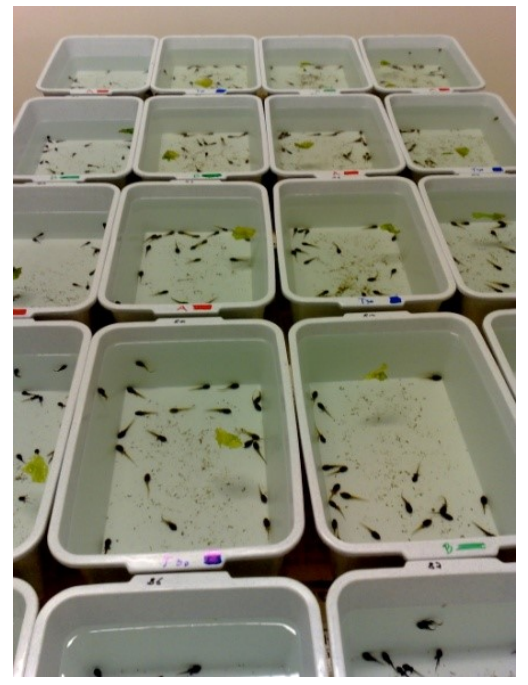

Figure 2: Water basins in an amphibian laboratory.

Water samples of some sub-experiments of study 1 were analyzed by Institute of Hygiene and Institute of Endocrinology of Graz University prior to the experiment. No pollutants such as heavy metals or chlorine and iodine were found.

Inter-rater reliability in counting animals that had reached the four-legged stage was assessed in collaboration with different authorities from Institute of Zoology of Graz University as well as from the Environmental Agency of Styria County. Some counting results were also documented photographically.

A total of 20 type (1) experiments were performed by five independent researchers (P. C. Endler, Institute of Zoology, Graz University; Waltraud Scherer-Pongratz, Boltzmann Institute, Graz; Christa Zausner-Lukitsch, Institute of Zoology, Vienna University; Heimo Lassnig, Federal Institute of Veterinary Investigation, Graz; Roeland van Wijk, Institute of Molecular Cell Biology, Utrecht University).

Temperature ranged between $18-27^{\circ} \mathrm{C}$ in the experiments performed in the 1990 s [3] and was $21 \pm 1^{\circ} \mathrm{C}$ in the 2000s [4].

No two-legged stage animals were lost. On the few occasions when a four-legged stage animal died it was counted as four-legged and removed from the basin.

All experiments were performed blind. Each laboratory had its own independent authority responsible for the blinding procedure. The code was not made known until after the presentation of results. For reasons of laboratory convenience (danger of cross-contamination due to intricate handling) we abstained from using more than one vial per substance.

When comparing and evaluating the data we had to take into account that experiments in highland amphibian varied in duration (most ranging $8-14$ days, but some taking up to 26 days). This problem in comparing and pooling data from several experiments has been approached in several manners in earlier publications, for example, by considering quartiles of the total duration, as proposed by Roeland van Wijk, formerly Utrecht University [3] or by normalizing data with respect to time based on the development of animals of water 30x-control group [11, p 162], as recommended by Rainer Lüdtke, a former member of the Institute for Medical Information Processing of Tübingen University (then) employed by the Carstens Foundation, Essen. 
As a whole, all the different methods of presenting and pooling data led to same tendency results. However, we had set ourselves the task of defining a generally applicable pooling method for metamorphosis experiments on amphibian larvae. Together with statistician Harald Lothaller (formerly Graz University) we reviewed the various methods used in the past and finally arrived at the following procedure. Here, normalization with respect to time was done on the assumption that differences in metamorphosis speed attributable to treatment would override differences in duration between experiments.

Measuring points for assessment were defined on the basis of the joint mean value of thyroxine 30x and water 30x groups at defined time-points in order to avoid artificial differences in variability. This was done using the following standard procedure. The range from $0 \%$ to $100 \%$ over which the means of four-legged animals progress in the course of an experiment is divided into 10\%-intervals (10\% reference points, RP). Table 1 gives a hypothetical example.

Table 1: Example illustrating the definition of measuring points for assessment by individual experiment. "c.": counts, sequence measurements; test group $(\mathrm{N}=100)$; control group $(\mathrm{N}=100)$ : number of animals at the four-legged stage; mean: mean of raw data from test + control group; RP: $10 \%$ reference points. For explanation, see text.

\begin{tabular}{lccccccccc}
\hline & c.0 & c.1 & c.3 & c.4 & c.5 & c.6 & c.7 & c.8 & c.9 \\
\hline test group & 0 & 8 & 28 & 39 & 46 & 57 & 66 & 77 & 87 \\
\hline $\begin{array}{l}\text { control } \\
\text { group }\end{array}$ & 0 & 13 & 34 & 45 & 53 & 65 & 74 & 88 & 94 \\
\hline & & & & & & & & & \\
\hline mean & 0 & 10.5 & 31 & 42 & 49.5 & 61 & 70 & 82.5 & 90.5 \\
\hline RP & RP00 & RP10 & RP30 & RP40 & RP50 & RP60 & RP70 & RP80 & RP90 \\
\hline
\end{tabular}

Each mean value is thus assigned to the $10 \%$ reference point to which it is closest (e.g. values between $46 \%$ and 54\% are all assigned to reference point 50). If a reference point remains without a value assigned to it (e.g., in an experiment with $30 \%$ following immediately after $10 \%$, reference point 19 ), the mean between the next lower and the next higher value is formed and assigned to that reference point (table 2).

Table 2: Example of an experiment with $31 \%$ following immediately after $10.5 \%$. Further details, see table 1.

\begin{tabular}{|c|c|c|c|c|c|c|c|c|c|c|}
\hline & c.0 & c. 1 & & c. 3 & c. 4 & c.5 & c. 6 & c. 7 & c. 8 & c.9 \\
\hline test group & 0 & 8 & & 28 & 39 & 46 & 57 & 66 & 77 & 87 \\
\hline $\begin{array}{l}\text { control } \\
\text { group }\end{array}$ & 0 & 13 & & 34 & 45 & 53 & 65 & 74 & 88 & 94 \\
\hline mean & 0 & 10.5 & $(10.5+31) / 2$ & 31 & 42 & 49.5 & 61 & 70 & 82.5 & 90.5 \\
\hline $\mathbf{R P}$ & RP00 & RP10 & RP20 & RP30 & $\mathrm{RP} 40$ & RP50 & RP60 & RP70 & RP80 & RP90 \\
\hline
\end{tabular}


If two consecutive values have the same distance from a reference point, their mean is calculated and assigned in their place to that reference point. Thus, each reference point is assigned a value giving the mean of four-legged animals at that point on the relative scale.

Subsequent analysis was then based on the individual values for thyroxine 30x and water 30x groups that corresponded to the joint $10 \%$ reference point. This procedure permits: a) graphical comparison and b) pooling of sub-experiments.

Means were calculated at basin level, while standard deviations were calculated at basin and experiment level. Chi-square test was performed for the measuring point when about $70 \%$ of all animals had reached the four-legged stage: frequencies (two-legged test animals / two-legged control animals / four-legged test animals / four-legged control animals) were entered in two-by-two-tables.

At that measuring point, the effect size (Cohen's d, standardized difference of means $=$ absolute difference between means of verum and control group, divided by S.D.) was calculated. Effect size $>0.2$ is regarded as small, $>0.5$ as medium and $>0.8$ as large.

\section{(2) Hyperstimulated highland animals and thyroxine 30x}

Study type (2) concerns the influence of thyroxine 30x compared to water 30x, on tyroxine hyperstimulated highland animals. Rana temporaria larvae were taken from a highland biotope $(1,400 \mathrm{~m}$ above sea level, southern Styria) [5].

Animals were pretreated in an aqueous molecular thyroxine dilution $\left(10^{-8}\right.$ parts by weight in basin water, hyperstimulation) from the two-legged stage on. One group of these hyperstimulated animals was then treated with thyroxine 30x and another group with analogously prepared water as control.

Furthermore, an inert control group remained untreated, i.e. received plain water for blinding purposes. Development was monitored by documenting the number of animals that entered the four-legged stage.

A total of 10 type (2) experiments) were performed by four researchers independently: Sonja U. Welles, Erika Suanjak-Treidl, Sabrina Weber, Waltraud Scherer-Pongratz (all Interuniversity College Graz).

As hyperstimulation speeds up development by about $20 \%$ by itself, chi-square test was performed for the measuring point when about $90 \%$ of all animals had reached the four-legged stage.

For further details on methods, see above studies type (1).

\section{Results}

\section{(1) Inert highland animals and thyroxine 30x}

A total of 20 sub experiments comprising 60 - 100 animals per group were performed (table 3) of study type (1). In most experiments, a clear trend could be found showing T30x-animals to be slower than W30x-animals. Due to the small figures in the individual sub-experiments, most differences were not statistically significant $(\mathrm{p}>0.05)$. 
Table 3: Survey of sub-experiments on the influence of extremely diluted agitated thyroxine on nonhyperstimulated (inert) highland amphibians. Exp, number of sub-experiment; probe, reference W30x (normalized) or T30x (relative differences between W30x- and T30x-groups in \%); year, year in which the experiment was performed; N, number of animals per group. For further details, see text.

\begin{tabular}{|c|c|c|c|c|c|c|c|c|c|c|c|c|c|c|c|}
\hline \multirow[t]{4}{*}{$\exp$} & \multirow[t]{3}{*}{ probe } & \multicolumn{10}{|c|}{ reference point $=\%$-step } & \multirow[t]{2}{*}{ researcher } & \multirow[t]{2}{*}{ lab } & \multirow[t]{2}{*}{ year } & $\mathbf{N}$ \\
\hline & & 1 & 2 & 3 & 4 & 5 & 6 & 7 & 8 & 9 & 10 & & & & \\
\hline & & $0 \%$ & $10 \%$ & $20 \%$ & $30 \%$ & $40 \%$ & $50 \%$ & $60 \%$ & $70 \%$ & $80 \%$ & $90 \%$ & & & & \\
\hline & W30x & 0 & 0 & 0 & 0 & 0 & 0 & 0 & 0 & 0 & 0 & & & & \\
\hline 1 & T30x & 0 & -2 & -2 & 0 & -2 & -3 & -5 & -7 & -5 & -3 & Endler & Graz 1 & 1990 & 80 \\
\hline 2 & T30x & 0 & 0 & -1 & -2 & -2 & -1 & -1 & -4 & -6 & -5 & Endler & Graz 1 & 1990 & 64 \\
\hline 3 & T30x & 0 & -1 & -4 & -5 & -7 & -8 & -10 & -10 & -11 & -13 & Endler & Graz 1 & 1990 & 80 \\
\hline 4 & T30x & 0 & -8 & -5 & -7 & -10 & -10 & -7 & -10 & -16 & -12 & Scherer & Graz 2 & 1990 & 95 \\
\hline 5 & T30x & 0 & -8 & -17 & -21 & -14 & -23 & -16 & -11 & -1 & -2 & End/Scher & Graz 1/2 & 1990 & 70 \\
\hline 6 & T30x & 0 & 1 & 1 & 2 & 2 & -1 & -7 & -5 & -2 & 1 & van Wijk & Utrecht & 1990 & 90 \\
\hline 7 & T30x & 0 & 3 & 7 & -8 & -8 & -10 & -13 & -8 & -3 & -1 & van Wijk & Utrecht & 1990 & 90 \\
\hline 8 & T30x & 0 & -4 & -4 & -15 & -15 & -4 & -4 & -11 & -7 & -7 & Scherer & St. Oswald & 1993 & 72 \\
\hline 9 & T30x & 0 & -1 & -5 & -17 & -17 & -15 & -17 & -25 & -26 & -26 & Scherer & St. Oswald & 1993 & 72 \\
\hline 10 & T30x & 0 & -1 & 9 & 19 & 9 & 9 & 5 & -2 & -2 & -2 & Scherer & St. Oswald & 1993 & 86 \\
\hline 11 & T30x & 0 & -2 & -6 & -4 & -5 & -5 & -5 & -5 & -4 & -6 & Scherer & Weiz & 1999 & 100 \\
\hline 12 & T30x & 0 & -2 & -9 & -5 & -2 & -2 & -2 & -5 & -5 & -3 & Scherer & Weiz & 1999 & 100 \\
\hline 13 & T30x & 0 & -1 & -3 & -6 & -11 & -2 & -1 & 0 & 0 & -1 & Scherer & Weiz & 1999 & 100 \\
\hline 14 & T30x & 0 & 0 & -5 & -8 & 1 & 1 & 2 & 1 & 4 & 3 & Scherer & Weiz & 1999 & 100 \\
\hline 15 & T30x & 0 & -2 & -4 & -8 & -11 & -14 & -16 & -13 & -10 & -10 & Lassnig & Graz 3 & 2000 & 60 \\
\hline 16 & T30x & 0 & -7 & -17 & -5 & -5 & -7 & -4 & -3 & -3 & -2 & Zausner & Wien & 2000 & 60 \\
\hline 17 & T30x & 0 & -1 & -2 & -6 & -11 & -15 & -14 & -14 & -15 & -10 & Zausner & Wien & 2000 & 60 \\
\hline 18 & T30x & 0 & -5 & -5 & -5 & -8 & -6 & -8 & -9 & -8 & -9 & Scherer & Weiz & 2000 & 60 \\
\hline 19 & T30x & 0 & -2 & -5 & -7 & -7 & -7 & -12 & -10 & -10 & -10 & Scherer & Weiz & 2000 & 60 \\
\hline 20 & T30x & 0 & -6 & -3 & -1 & -3 & -3 & -2 & -3 & -9 & -7 & Scherer & Weiz & 2001 & 100 \\
\hline
\end{tabular}


As observed by all five different researchers involved ( $p<0.05$ or 0.01 at the $70 \%$-measuring point), highland animals reacted to thyroxine 30x slowing down metamorphosis compared to water 30x (figure 3). This holds true for both 1990s and 2000s experiments. The overall inhibiting effect at the $70 \%$ measuring point was statistically significant $(\mathrm{p}<0.01) ; 1$. S.D. was about $\pm 8 \%$ at basins level both in the test and control groups, and about $\pm 4 \%$ at sub-experiments level, whereas the effect size was 0.76 (medium) at basins level and 1.6 (large) at sub-experiments level.

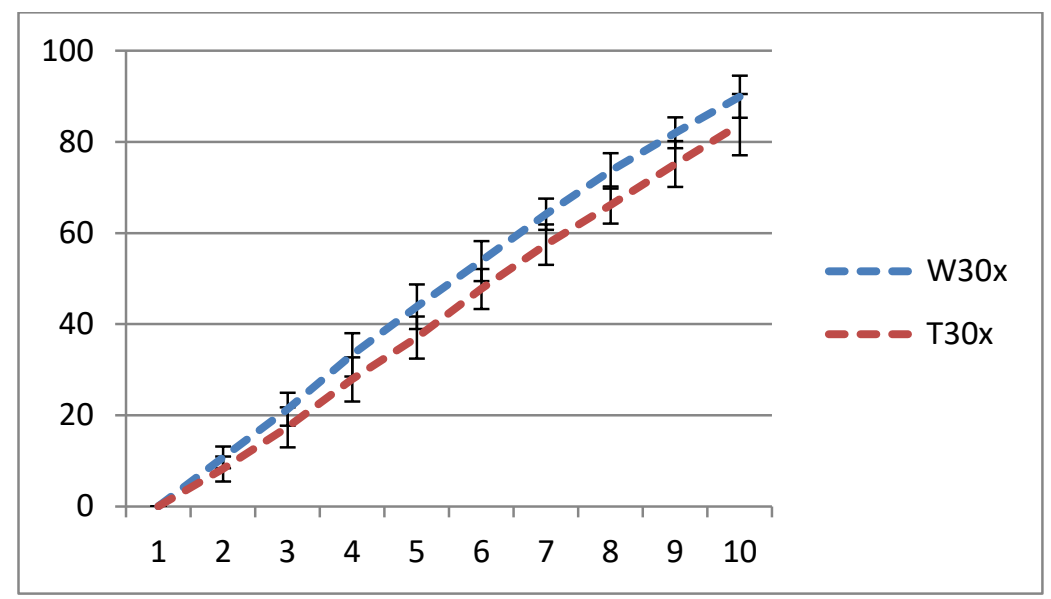

Figure 3: Influence of extremely diluted and agitated thyroxine on inert (non-hyperstimulated) highland amphibians. Pooled data from five researchers [6-7]. $\mathrm{N}=1,650$ per group. Ordinate $=$ cumulative frequency of four-legged tadpoles in \%. Abscissa = time-points. Error bars represent 1 S.D. at individual experiments level. For further explanation, see text.

Raw data and the method of calculating \%-measuring points and graphs for sub-experiments can be inferred from Table 4 (available as a supplementary file - format xls [20]).

Table 4: Details on sub-experiments on the influence of extremely diluted and agitated thyroxine on nonhyperstimulated (inert) highland amphibians. ST: "steps of ten": see Methods; black figures: raw data; blue: sums of raw data from T30x + W30x groups for calculation of "ST"; red: application of "ST" to T30x + W30x groups separately. For further explanation, see Table 3, Figure 3 and text.

\section{(2) Highland animals and thyroxine 30x - hyperstimulated animals}

A total of 10 study type (2) experiments comprising 100 animals per group were performed (table 5). In most experiments a trend could be found showing T30x-animals to be slower than W30x-animals. Due to the small figures in the individual sub-experiments, most differences were not statistically significant $(p>0.05)$.

As a trend observed by three out of 4 researchers involved, thyroxine 30x-animals metamorphosed slower than water 30x-animals (figure 4). At the 90\%-measuring point for the pooled data, this slowing down was statistically significant $(\mathrm{p}<0.01) .1$ S.D. was $\pm 7 \%$ at basins level and $\pm 3 \%$ at experiments level, whereas effect size was 0.4 (small) at basins level and 0.97 (large) at experiments level. 
Table 5: Survey of sub-experiments on the influence of extremely diluted and agitated thyroxine on hyperstimulated highland amphibians. For details, see table 1 and text.

\begin{tabular}{|c|c|c|c|c|c|c|c|c|c|c|c|c|c|c|c|}
\hline \multirow[t]{4}{*}{$\exp$} & \multirow[t]{3}{*}{ probe } & \multicolumn{10}{|c|}{ reference point $=\%$-step } & \multirow[t]{3}{*}{ researcher } & \multirow[t]{3}{*}{ lab } & \multirow[t]{3}{*}{ year } & \multirow[t]{3}{*}{$\mathbf{N}$} \\
\hline & & 1 & 2 & 3 & 4 & 5 & 6 & 7 & 8 & 9 & 10 & & & & \\
\hline & & $0 \%$ & $10 \%$ & $20 \%$ & $30 \%$ & $40 \%$ & $50 \%$ & $60 \%$ & $70 \%$ & $80 \%$ & $90 \%$ & & & & \\
\hline & $\mathrm{T}+\mathrm{W} 30 \mathrm{x}$ & 0 & 0 & 0 & 0 & 0 & 0 & 0 & 0 & 0 & 0 & & & & \\
\hline 1 & $\mathrm{~T}+\mathrm{T} 30 \mathrm{x}$ & 0 & -7 & 4 & 1 & -2 & -5 & -11 & -10 & -10 & -9 & Scherer & Weiz & 1999 & 100 \\
\hline 2 & $\mathrm{~T}+\mathrm{T} 30 \mathrm{x}$ & 0 & -4 & 7 & 5 & 4 & 2 & -2 & -6 & -10 & -14 & Scherer & Weiz & 1999 & 100 \\
\hline 3 & $\mathrm{~T}+\mathrm{T} 30 \mathrm{x}$ & 0 & -3 & -2 & -5 & -7 & -10 & 0 & -3 & -7 & -10 & Scherer & Weiz & 1999 & 100 \\
\hline 4 & $\mathrm{~T}+\mathrm{T} 30 \mathrm{x}$ & 0 & -1 & 2 & -1 & -4 & -7 & -10 & -8 & -7 & -5 & Scherer & Weiz & 1999 & 100 \\
\hline 5 & $\mathrm{~T}+\mathrm{T} 30 \mathrm{x}$ & 0 & $-2,5$ & -3 & -3 & -3 & -6 & -4 & -2 & $-2,5$ & -3 & Scherer & Weiz & 2002 & 100 \\
\hline 6 & $\mathrm{~T}+\mathrm{T} 30 \mathrm{x}$ & 0 & -5 & -7 & -13 & -8 & -8 & -7 & -6 & -6 & -6 & Scherer & Weiz & 2002 & 100 \\
\hline 7 & $\mathrm{~T}+\mathrm{T} 30 \mathrm{x}$ & 0 & -1 & -2 & -6 & -9 & -5 & -3 & -4 & -5 & -7 & Scherer & Weiz & 2003 & 100 \\
\hline 8 & $\mathrm{~T}+\mathrm{T} 30 \mathrm{x}$ & 0 & 2 & -2 & -8 & -13 & -13 & -14 & -14 & -5 & -4 & Suanjak & Weiz & 2004 & 100 \\
\hline 9 & $\mathrm{~T}+\mathrm{T} 30 \mathrm{x}$ & 0 & -5 & -3 & 2 & 1 & 1 & 0 & 1 & 2 & -2 & Weber & Weiz & 2005 & 100 \\
\hline 10 & $\mathrm{~T}+\mathrm{T} 30 \mathrm{x}$ & 0 & -3 & -6 & -9 & -12 & -15 & -18 & -11 & -3 & 0 & Welles & Weiz & 2005 & 60 \\
\hline
\end{tabular}

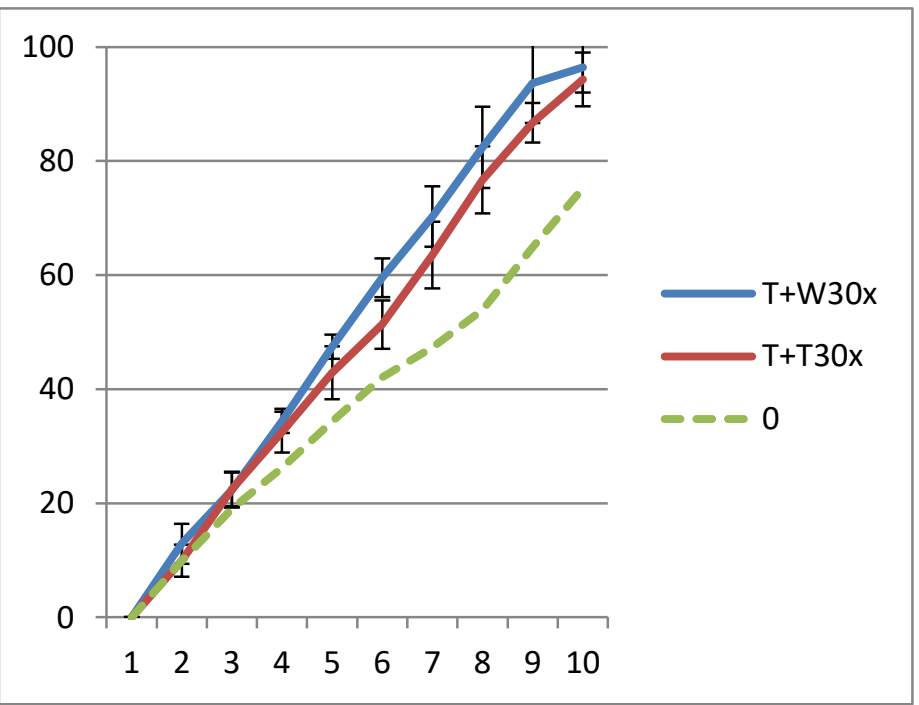

Figure 4: The influence of extremely diluted and agitated thyroxine on hyperstimulated highland amphibians. Pooled results from four researchers. T+, hyperstimulation with molecular thyroxine; 0, inert (non-hyperstimulated) control treated with plain water for blinding purposes. $\mathrm{N}=1000$ per group. For further explanation, see Fig. 1 caption and text. 
Raw data, the method of calculating \%-measuring points and graphs for sub-experiments can be inferred from Table 6 (available as a supplementary file - format xls [20]).

Table 6: Details on sub-experiments on the influence of extremely diluted and agitated thyroxine on nonhyperstimulated (inert) highland amphibians. For explanation, see Table 3.

\section{Discussion}

Experiments on amphibian metamorphosis can vary considerably in duration. We had set ourselves the task of defining a generally applicable pooling method for such metamorphosis experiments. The problem of artificial differences in variability when comparing and pooling data from several experiments was approached by normalization respect to time based on the development of both test and control animals. This was done on the assumption that differences in metamorphosis speed attributable to treatment would override differences in duration between experiments.

Using this normalization method, we present here full details of the results obtained by our experiments on highland Rana temporaria treated with thyroxine 30x over the course of two decades (1990 - 2010). Differences found between treatment groups thus calculated were in line with those obtained with other pooling methods [3-5].

Thyroxine 30x does slow down metamorphosis in inert highland amphibians. This was observed by five researchers in 20 sub-experiments, and it seems to be the most reliable bio-assay found in our amphibian research so far. When the experiment was performed with animals pretreated by hyperstimulation with molecular thyroxine, slow down of metamorphosis was again observed (by three out of four researchers) in most of the 10 sub-experiments.

However, pretreatment (hyperstimulation) of these highland animals with molecular thyroxine did not lead to a more marked effect of homeopathic dilution 30x; rather the effect was smaller compared no pretreatment. Although the amphibian model was inspired by effects observed in intoxication / detoxification experiments [13-16], and pretreatment by hyperstimulation with molecular thyroxine significantly enhanced the effect of a low potency of that hormone, the results obtained are not suggestive of an intoxication / detoxification mechanism.

The results presented here were independently corroborated by J.R.P. Guedes [8,9] from Brazil, who studied the influence of homeopathic high dilutions prepared from thyroid glands rather than pure thyroxine on amphibian metamorphosis. In line with our experiments, decrease in metamorphosis speed was found in the group treated with the high dilution containing thyroid hormones [8]. Guedes et al. also investigated histological changes during tail absorption and found more apoptosis (programmed cell death) in the test group [10]. Apoptosis, a process normally controlled by the cell own genetic code, plays a key role in embryogenesis and the elimination of tissue no longer needed that attends metamorphosis. It can be triggered by receptor binding, protease activity or other mechanisms. Thus it appears plausible to consider intervention into this control system as one possible path of action of the homeopathic high dilution. However, in keeping with our principle of avoiding invasive methods, we chose not to pursue this question any further.

Moreover, in 2010, a guest researcher from Kollegiale Instanz für Komplementärmedizin of Bern University (Gabriele Bach) performed a pilot study at the laboratory of Interuniversity College in order to test this methodology (1) with regards to a fully independent follow-up study in Switzerland. A total of 70+70 highland Rana temporaria animals were involved. In line with the previous observations in the 1990s and 2000s, 
animals reacted to thyroxine 30x with slowing down of metamorphosis compared to water $30 \mathrm{x}(-11 \%$ at the $70 \%$-measuring point). Although the effect size was large (0.92), due to the small number of animals in this pilot study, differences were not statistically significant at chi-square test ( $p>0.05)$ [10] (figure 5).

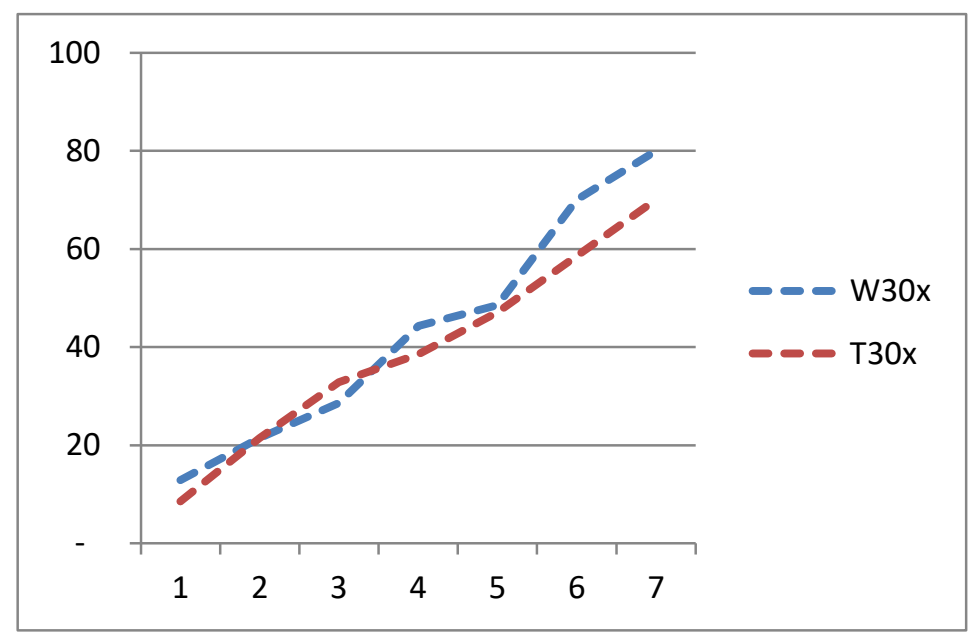

Figure 5: The influence of extremely diluted and agitated thyroxine on inert highland amphibians. Data from an independent pilot / feasibility study [10]. N = 70 per group. For further explanation, see Fig. 4 caption and text. From [10], modified.

Detailed information on our experiments with lowland amphibians is provided in $[17,18]$. The adventure of our homeopathic amphibian research is described in the narrative book 'Homeopathy - An Expedition Report' [19].

\section{References}

[1] König K. [On the effect of extremely attenuated ("homeopathic") dilutions of metallic salts on the development and growth of tadpoles]. Über die Wirkung extrem verdünnter ("homöopathischer") Metallsalzlösungen auf Entwicklung und Wachstum von Kaulquappen. Zschft ges exp Med 1927; 56: 881-893.

[2] Endler PC, Schulte J. (eds.). Ultra High Dilution: Physiology and Physics. Kluwer Academic Publishers, Dordrecht 1994.

[3] Endler PC, Pongratz W, Van Wijk R, Kastberger G, Haidvogl M. Effects of highly diluted succussed thyroxine on metamorphosis of highland frogs. Berlin J Research Hom 1991; 1(3): 151-160.

[4] Zausner C, Lassnig H, Endler PC, Scherer W, Haidvogl M, Frass M, Kastberger G, Lüdtke R. [The effect of "homeopathically" prepared thyroxine on the metamorphosis of highland amphibians. Results of a multicentric control study. Die Wirkung von "homöopathisch" zubereitetem Thyroxin auf die Metamorphose von Hochlandamphibien. Ergebnisse einer multizentrischen Kontrollstudie. Perfusion 2002; 17: 268-276. 
[5] Welles SU, Endler PC, Scherer-Pongratz W, Suanjak-Traidl E, Weber S, Frass M, Spranger H, Lothaller H. Pretreatment with thyroxine (10e-8) and the effect of homeopathically prepared thyroxine (10-30) on highland frogs - a multi-researcher study. Res Compl Med / Forsch Komplementärmed 2007; 14: 353-357.

[6] Endler PC, Lüdtke R, Heckmann C, Zausner C, Lassnig H, Scherer-Pongratz W, Haidvogl M, Frass M. Pretreatment with thyroxine (10e-8 parts by weight) enhances a "curative" effect of homeopathically prepared thyroxine (10e-13) on lowland frogs. Res Compl Med / Forsch Komplementärmed 2003; 10: 137-142.

[7] Endler PC, Pongratz W, Kastberger G, Wiegant FAC, Schulte J. The effect of highly diluted agitated thyroxine on the climbing activity of frogs. J. Vet. Hum. Tox. 1994; 36: 56-59.

[8] Guedes JRP, Ferreira CM, Guimaraes HMB, Saldiva PHN, Capelozzi VL. Homeopathically prepared dilution of Rana catesbeiana thyroid glands modifies its rate of metamorphosis. Homeopathy 2004; 93: 132 137.

[9] Guedes JRP. [Homeopathic ultradilution of triiodothyronine alters cellular apoptosis of the tail of Rana catesbeiana tadpoles: in vitro]. Ultradiluicao homeopatica de triiodotironina altera a apoptose celular da cauda de girinos de Rana catesbeiana: in vitro. [dissertation] Sao Paulo University, 2009.

[10] Interuniversity College. [Pilot trial aimed at an independent replication of a study on the possibility of influencing the speed of metamorphosis of amphibian larvae by means of homeopathically diluted thyroxin (10e-30) by G. Bach, Cooperative Office for Complementary Medicine of Bern University. Report to the Government of the State of Styria.] Pilotversuch zur unabhängigen Wiederholung einer Studie zur Beeinflussung der Metamorphosegeschwindigkeit von Amphibienlarven durch homöopathisch verdünntes Thyroxin (10e-30) durch G. Bach, Kollegiale Instanz für Komplementärmedizin der Universität Bern. Bericht an das Amt der Steiermärkischen Landesregierung, Graz 2011.

[11] Schulte J, Endler PC (eds.). Fundamental Research in Ultra High Dilution and Homoeopathy. Kluwer Academic Publishers, Dordrecht, 1998.

[12] Gosner KL. A Simplified Table for Staging Anuran Embryos and Larvae with Notes on Identification. Herpetologica 1960; 16: 183-190.

[13] Roth C. Literature review and critical analysis on the topic of "In- and Detoxication Experiments in Homeopathy". Berlin Res J Hom 1991; 1: 111-117.

[14] Göldner C. [Review and evaluation of new toxicological experiments performed with homeopathic preparations.] Review und Evaluierung von neuen, mit homöopathischen Zubereitungen durchgeführten toxikologischen Experimenten. [Dissertation] University of Graz 2006.

[15] Endler PC, Thieves K, Reich R, Matthiessen PF, Bonamin L, Scherr C, Baumgartner S. Repetitions of fundamental research models for homeopathically prepared dilutions beyond 10e-23: a bibliometric study. Homeopathy 2010; 99: 25-36.

[16] Endler PC Curative Effects of Homeopathically Prepared Thyroxin on Thyroxin-Hyperstimulated Amphibians? Doctoral thesis, Azteca University, Chalco 2010.

[17] Endler P.C., Scherer-Pongratz W., Lingg G., Lothaller H. Amphibian metamorphosis and its inhibition by homeopathically prepared thyroxine - multi researcher studies 1990-2010. Paper accepted by Frontiers of Biosciences 2011. 
[18] Kiefer P, Lingg G, Endler PC. Lowland amphibians - recalculation of data on effects of diluted thyroxine. Int J High Dilution Res [online]. 2012 [cited 2011 Dec 20]; 11(38) [in press]

[19] Endler PC, Homeopathy research - an expedition report. An old healing system gains plausibility. edition@inter-uni.net, Graz 2003.

[20] Lingg G, Endler PC. Highland amphibians - Recalculation of data from 1990 to 2010 on the effects of extremely diluted thyroxine [supplementary material]. Int J High Dilution Res [online]. 2011 [cited YYYY Month dd]; 10(37): 298-311. Available from: http://www.feg.unesp.br/ ojs/index.php/ijhdr/article/view/429/540

\title{
Anfíbios de terras altas - recálculo de dados entre 1990 e 2010 sobre os efeitos de tiroxina em alta diluição
}

\begin{abstract}
RESUMO
Os experimentos sobre metamorfose em anfíbios podem variar consideravelmente em sua duração. Os autores se propuseram a tarefa de definir um método para reunir dados de aplicação geral em experimentos sobre metamorfose. $\mathrm{O}$ problema das diferenças artificiais na variabilidade ao comparar e reunir os dados de vários experimentos foi abordado através de normalização em relação ao tempo baseada no desenvolvimento dos animais de ambos grupos teste e controle. A faixa entre $0 \%$ e $100 \%$ na qual progride a fração de animais de quatro patas no curso do experimento é dividida em intervalos de $10 \%$ e esses pontos de referencia $10 \%$ são mapeados numa escala correspondente. Cada medição é então atribuída ao ponto mais próximo na escala temporal. Desta maneira, cada ponto de referencia recebe um valor que representa o número ou porcentagem de animais de quatro patas nesse ponto da escala. A análise subsequente se baseou nos valores individuais dos grupos teste e controle que correspondiam ao ponto de referencia conjunto $10 \%$. A normalização em relação ao tempo foi realizada com base na suposição de que as diferencias em velocidade de metamorfose atribuíveis ao tratamento controlariam as diferenças d duração entre experimentos. Os resultados dos experimentos realizados no curso de duas décadas (1990-2010) em Rana temporaria de terras altas tratada com uma alta diluição de tiroxina preparada homeopaticamente ("30x") são presentados com todo detalhe com base no método de normalização. As diferenças achadas entre os grupos testados assim calculadas mostraram acordo com os obtidos através de outros métodos de reunião de dados. Tiroxina 30x de fato diminui a metamorfose em anfíbios de terras altas inertes. Isso foi observados por cinco pesquisadores em 20 sub-experimentos e parece ser o ensaio biológico em pesquisa anfíbia da homeopatia mais confiável até o presente. Quando os experimentos foram realizados com animais de terras altas pré-tratados através de hiperestimulação com tiroxina molecular, também se observou metamorfose mais lenta (por três de quatro pesquisadores) na maioria entre dez subexperimentos.
\end{abstract}

Palavras-chave: homeopatia, tiroxina, anfíbios

\section{Anfibios de tierras altas - Re-cálculo de datos entre 1990 y 2010 sobre los efectos de altas diluciones de tiroxina}


Los experimentos en metamorfosis en anfibios pueden variar considerablemente en su duración. Los autores se propusieron la tarea de definir un método de reunión de datos de aplicación general en experimentos de metamorfosis. El problema de las diferencias artificiales de la variabilidad al comparar y reunir datos de varios experimentos fue abordado mediante normalización en relación al tiempo con base en el desarrollo de los animales testeados y control. El espectro entre $0 \%$ y $100 \%$ en que progresa la fracción de animales de cuatro patas en del curso de un experimento es dividido en intervalos de $10 \%$ y los puntos de referencia $10 \%$ son mapeados en una escala correspondiente. En seguida se asigna cada medida al punto más próximo en la escala de tiempo. De esta manera, se asigna un valor a cada punto de referencia, que representa el número o porcentaje de animales de cuatro patas en ese punto de la escala. El análisis posterior se basó en los valores individuales de los grupos teste y control que correspondían al punto de referencia conjunto $10 \%$. La normalización respecto al tiempo fue realizada asumiendo que las diferencias en la velocidad de metamorfosis atribuibles al experimento cancelarían las diferencias en duración entre experimentos. Los resultados de los experimentos realizados en el curso de dos décadas (1990-2010) en Rana temporaria de tierras altas tratada con una alta dilución homeopáticamente preparada de tiroxina (“30x") son presentados con todo detalle, con base en este método de normalización. Las diferencias encontradas entre los grupos estudiados calculadas como descrito concuerdan con los obtenido mediante otros métodos de reunión de datos. Tiroxina 30x en efecto enlentece la metamorfosis en anfibios de tierras altas inertes. Esto fue observado for cinco investigadores en 20 sub-experimentos y parece ser el ensayo biológico más confiable en investigación anfibia sobre homeopatía más confiable hasta el presente. Cuando los experimentos fueron realizados en animales de tierras altas pre-tratados mediante hiperestimulación con tiroxina molecular, nuevamente se observó enlentecimiento de la metamorfosis (por tres de cuatro investigadores) en la mayoría de diez sub-experimentos.

Palabras-clave: homeopatía, tiroxina, anfibios

\section{(c)) BY-NC-ND Licensed to GIRI}

Support: authors declare that this study received no funding

Conflict of interest: authors declare there is no conflict of interest

Received: 29 May 2011; Revised: 28 June 2011; Published: 30 Dec 2011.

Correspondence author: Gerhard Lingg, Interuniversity College, Petrifelderstr. 4, 8042 Graz, Austria, e-mail: college@inter-uni.net

How to cite this article: Lingg G, Endler PC. Highland amphibians - Recalculation of data from 1990 to 2010 on the effects of extremely diluted thyroxine. Int J High Dilution Res [online]. 2011 [cited YYYY Month dd]; 10(37): 311-324. Available from: http://www.feg.unesp.br/ ojs/index.php/ijhdr/article/view/429/541 